\title{
Hubungan Tingkat Kecukupan Karbohidrat Dan Persen Lemak Tubuh Dengan Sindroma Pramenstruasi (PMS) Pada Remaja Putri
}

\section{Correlation between Carbohydrate Sufficiency and Percentage Fat Body Intake towards Premenstrual Syndrome (PMS) among Female Teenagers}

\author{
Shella Habibatul Illah Rahmadianta*, Sri Adiningsih
}

\begin{abstract}
ABSTRAK
Latar Belakang: Sindroma Pramenstruasi (PMS) banyak melanda remaja putri. Terdapat beberapa faKtor yang berkontribusi terhadap kejadian sindroma pramenstruasi seperti perubahan hormonal, status gizi, asupan makan, dan gaya hidup.

Tujuan: Tujian dari penelitian ini adalah untuk menganalisis hubungan tingkat kecukupan karbohidrat dan persen lemak tubuh dengan sindroma pramenstruasi (PMS) pada remaja putri di SMA Negeri 4 Bojonegoro

Metode: Penelitian ini dengan desaincross sectional. Populasi penelitian ini adalah siswi SMA Negeri 4 Bojonegoro. Hasil dari perhitungan random sampling didapat 110 siswi sebagai sampel. Pengumpulan data menggunakan pengukuran persen lemak tubuh untuk mendapatkan variabel persen lemak tubuh, pengisian form Estimated Food Recall 2×24 jam untuk mendapatkan variabel tingkat kecukupan karbohidrat.,dan menggunakan Moos Menstrual Distress Questionnare (MDQ) untuk mendapatkan variabel Sindroma Pramenstruasi. Data dianalisiss menggunakan uji spearman untuk mengetahui hubungan tingkat kecukupan karbohidrat dan persen lemak tubuh dengan sindroma pramenstruasi pada remaja putri .

Hasil: Hasil penelitian ini menunjukkan ada hubungan antara tingkat kecukupan karbohidrat dengan sindroma pramenstruasi $(p=0,010)$ dan tidak ada hubungan antara persen lemak tubuh dengan sindroma pramenstuasi pada remaja putri $(p=0,642)$. Kesimpulan: Terdapat hubungan antara tingkat kecukupan karbohidrat dan persen lemak tubuh dengan kejadian sindroma pramenstruasi pada siswi di SMA Negeri 4 Bojonegoro. Oleh karena itu, remaja putri dianjurkan untuk mengonsumsi karbohidrat sesuai kecukupan untuk mencegah kejadian sindroma pramenstruasi.
\end{abstract}

Kata kunci: Tingkat Kecukupan Karbohidrat, Persen Lemak Tubuh, PMS, dan Sindroma Pramenstruasi

\section{ABSTRACT}

Background: Premenstrual Syndromes are commonly found in many adolescent girls. There are several factors that contribute to the incidence of premenstrual syndrome such as hormonal change, nutritional status, food intake, and lifestyle.

Objectives: The purpose of this study was analyzing correlation of sufficiency of carbohydrate and percentage fat body with premenstrual syndrome in female teenagers at SMA Negeri 4 Bojonegoro

Methods: The research used cross sectional study. The sample size was 110 female students in SMA Negeri 4 Bojonegoro. The data were collected by measuring percentage body fat to obtain percentage body fat variable; $2 \times 24$ hours estimated food recall to obtain of carbohydrate sufficiency; and Moos Menstrual Distress Questionnare (MDQ) for premenstrual syndrome cases. The data were analyzed using spearman test to find out correlation between carbohydrat sufficiency and percentage fat body intake towards premenstrual syndrome (PMS) in female teenagers.

Result: The result of this study showed that there was correlation between sufficiency of carbohydrate) and Premenstrual Syndrome $(p=0.010)$. Beside that, there was also a not correlation between percentage body fat) and Premenstrual Syndrome (PMS) ( $p=0.642)$.

Conclusions: There was correlation between levels of carbohydrate intake with premenstrual syndrome in female teenagers and there was not corelation between percentage fat body with premenstrual syndrome in female teenagers of Senior High School 4 , Bojonegoro. Therefore, adolescent girls encouraged to increase carbohydrate intake to prevent the occurrence of premenstrual syndrome. 
Keywords: carbohydrat sufficiency, persentage body fat, PMS, premenstrual syndrome

\author{
Koresponden: \\ Shella Habibatul Illah Rahmadianta \\ Email: shellahir11@gmail.com \\ Departemen Gizi, Fakultas Kesehatan Masyarakat Universitas Airlangga, Surabaya
}

\section{PENDAHULUAN}

Sindroma Pramenstruasi (PMS) merupakan suatu keadaan dimana sejumlah gejala terjadi secara rutin dan berkaitan dengan siklus menstruasi ${ }^{1}$. PMS ditandai dengan perut kembung, payudara terasa nyeri, sakit kepala, daerah panggul terasa berat dan tertekan, kelelahan yang luar biasa, juga dapat menyebabkan kelainan kulit, nyeri perut bagian bawah, emosional, cemas, mood, dan mudah tersinggung. Waktu berlangsung terjadinya gejala sindroma pramenstruasi sekitar 7-10 hari sebelum menstruasi dan menghilang ketika saat menstruasi dimulai 2

Hampir 75\% wanita usia subur di seluruh dunia mengalami sindroma pramenstruasi (PMS) dan frekuensi gejala sindroma pramenstruasi (PMS) pada wanita Indonesia $80-90 \%{ }^{3}$. Penelitian (Retissu et al, 2010) menyatakan bahwa $90 \%$ perempuan mengalami Sindroma Pramenstruasi (PMS). Sebanyak 30-50\% wanita mengalami gejala sindroma pramenstruasi (PMS), 5\% merasakan gejala cukup parah dan $10 \%$ mengalami gejala sangat parah yang berakibat ketidakhadiran di sekolah ataupun di tempat kerja selama 1-3 hari setiap bulannya ${ }^{5}$. Sekitar $80-$ 95\% perempuan usia 16-45 tahun mengalami gejala-gejala sindroma pramenstruasi (PMS) yang dapat mengganggu ${ }^{6}$. Penelitian yang dilakukan di SMU Sejahtera Surabaya didapatkan 39,2\% mengalami gejala berat dan 60,8\% mengalami gejala ringan ${ }^{7}$. Terjadinya siklus menstruasi yang tidak teratur harus diperhatikan oleh setiap wanita sejak awal terjadinya menstruasi, yakni pada usia remaja sehingga tidak menimbulkan dampak bagi kesehatan khususnya pada reproduksi seperti terjadinya infertilitas pada wanita ${ }^{8}$.

Prevalensi rata-rata wanita usia 10-59 tahun yang mengalami gangguan sindroma pramenstruasi di Indonesia sebesar $13,7 \%$. Sementara prevalensi DKI Jakarta menjcapai $17,2 \%{ }^{9}$. Pada penelitian Sianipar pada tahun 2009 dilakukan disebuah Sekolah Menengah Atas di Jakarta menunjukkan bahwa terdapat $63,2 \%$ responden mengalami gangguan menstruasi dengan gangguan pada kejadian sindroma pramenstruasi sebesar $5,0 \%{ }^{10}$. Pada studi dilakukan di beberapa negara bagian barat didapatkan hubungan antara hormon, asupan makanan, dan berat badan yang dinilai melalui status gizi terhadap gangguan sindroma pramenstruasi ${ }^{11}$. Status gizi secara langsung dipengaruhi oleh beberapa faktor diantaranya asupan gizi serta usia menarche. Umunya remaja yang memiliki berat badan lebih juga memiliki masa lemak yang lebih dan cenderung mengalami menarche dini. Perlambatan menarche atau biasa disebut pubertas terda terjadi diatas uisa 18 tahun, salah satu kemungkinanya akibat nutrisi berat ${ }^{12}$. Persen lemak tubuh mrupakan salah satu aspek yang dapat digunakan untuk melihat ada tidaknya masalah gizi. Persen lemak tubuh dapat mencerminkan proporsi komposisi tubuh. Apabila presentase lemak tubuh seseorang lebih tinggi dari angka normal, artinya masa lemak tubuh orang tersebut berlebihan ${ }^{13}$. Beberapa faktor yang mempengaruhi masa lemak tubuh seseorang antara lain konsumsi karbohidrat, persen lemak tubuh, serta sindroma pramenstruasi ${ }^{14}$

Menurut Winkjoastro pada tahun 2005 mengenai status gizi gemuk erat kaitannya dengan lemak yang lebih tinggi. Jaringan lemak ini akan menghasilkan hormon leptin yang memicu peningkaran Letunizing Hormone (LH) yang berfungsi sebagai sekresi estrogen dan progesteron. Semakin tinggi hormon LH maka produksi hormon estrogen dan progesteron yang berada di ovarium juga akan meningkat. Kadar hormon leptin ini dikaitkan dengan kejiadian persen lemak tubuh yang mengakibatkan terjadinya sindroma pramenstruasi (PMS). Karakteristik remaja memiliki pola perilak konsumsi makanan yang tidak sehat terlihat dari karakteristik perilaku remaja saat ini sangat memperhatikan body image utamanya kebanyakan remaja melakukan diet yang terlalu ketat berdampak pada status gizinya. Mengurangi konsumsi makanan dengan melewatkan makan pagi, dan menahan rasa lapar, akibatnya mengonsumsi makanan cepat saji dan jajanan, seperti tinggi kalori, tinggi lemak, tinggi kolestrol, tinggi garam, dan rendah serat ${ }^{15}$. Body image kemungkinan akan berdampak pada asupan gizi, baik zat gizi makro maupun mikro yang dikonsumsi ${ }^{16}$. Berdasarkan penelitian yang dilakukan oleh Sitoayu pada tahun 2017 mengenai kecukupan zat gizi makro dengan sindroma pramenstruasi pada remaja putri di SMA Negeri 21 Jakarta menunjukkan bahwa ) terdapat hubungan antara kecukupan zat gizi makro berupa karbohidrat, protein, dan lemak dengan sindroma pramenstruasi ${ }^{17}$. Asupan karbohidrat memiliki hubungan dengan kalori selama fase luteal asupan protein berhubungan dengan fase folikuler, sedangkan asupan lemak berhubungan dengan hormon reproduksi ${ }^{18}$.

Remaja lebih memilih membeli makanan yang lebih praktis atau makanan cepat saji karena penyajiannya cepat sehingga hemat waktu dan dihidangkan kapan saja, dimana saja, tempat saji, dan penyajian yang higienis,

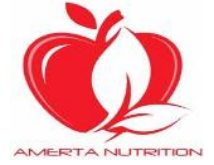

(C)2020. Rahmadianta dan Adiningsih. Open access under CC BY - SA license.

Received: 02-11-2019, Accepted: 10-01-2020, Published online: 15-03-2020.

doi: 10.20473/amnt. v4i1.2020. 23-29 Joinly Published by IAGIKMI \& Universitas Airlangga 
dianggap makanan bergengsi dan modern, juga makanan gaul bagi anak muda dan diolah secara sederhana ${ }^{19}$. Selain itu gangguan menstruasi yang disebabkan oleh kegagalan ovulasi merupakan dampak dari adanya stress yang memberi tekanan terhadap hormon GnRH, FSH, dan LH yang berhubungan dengan suatu terjadinya kejadian menstruasi ${ }^{20}$.Menurut ${ }^{21}$ lemak tubuh memiiki hubungan erat dengan IMT karena nilai IMT yang tinggi dapat mengindikasi lemak tubuh yang lebih tinggi. Setiap kenaikan $1 \mathrm{~kg} / \mathrm{m}^{2}$ pada IMT dikaitkan dengan peningkatan signifikan terhadap risiko sindroma pramenstruasi (PMS) sebesar $3,0 \%^{22}$ (. Hormon estrogen dalam tubuh wanita meningkat saat tubuh mengalami obesitas ${ }^{23}$.

Sindroma Pramenstruasi (PMS) dapat dipengaruhi oleh kebiasaan makan ${ }^{2}$. Kebiasaan makan adalah suatu istilah untuk menggambarkan kebiasaan dan perilaku yang berhubungan dengan makanan dan makan seperti pola makanan yang dimakan, frekuensi dan porsi makanan yang di makan. Makanan yang mengandung zat gizi makro dan garam relatif tinggi cenderung banyak disukai oleh golongan remaja pada umunya. Salah satu zat gizi makro adalah karbohidrat. Makanan yang mengandung karbohidrat seperti roti, kentang, jagung, gandum, dan oat membantu meringankan gejala sindroma pramenstruasi terutama berkaitan dengan mood ${ }^{24}$. Karbohidrat berperan dalam meningkatkan gula darah. Ketika tingkat gula darah turun, tubuh mengeluarkan adrenalin yang menghentikan efektifitas hormon progesterone yang membantu penyembuhan gula darah ${ }^{24}$. Sedangkan karbohidrat dapat mempengaruhi kejadian sindroma pramenstruasiapabila suatu kebutuhan akan asupan zat gizi tersebut tidak tercukupi. Asupan karbohidrat yang tidak tercukupi dapat meningkatkan resiko terjadinya sindroma pramenstruasi $(\mathrm{PMS})^{25}$. Gejala yang timbul bahkan dapat menyebabkan gangguan pada pekerjaan dan gaya hidup seseorang ${ }^{26}$. Hal tersebut dikarenakan persentase lemak dalam tubuh dan lemak tubuh mempengaruhi proses pembentukan hormon estrogen yang merupakan faktor dominan penyebab sindroma pramenstruasi ${ }^{2}$

Tujuan dari penelitian ini adalah untuk menganalisis hubungan tingkat kecukupan karbohidrat dan persen lemak tubuh dengan kejadian sindroma pramenstruasi (PMS) pada remaja putri.

\section{METODE}

Desain pada peneltian ini menggunakan metode cross sectional. Penelitian dilakukan padabulan Agustus 2019. Sampel pada penelitian ini adalah remaja putri yang merupakan siswi kelas $\mathrm{X}$ dan XI di SMA Negeri 4 Bojonegoro tahun ajaran 2019/2020 yang sudah pernah mengalami menstruasi. Populasi dalam penelitian ini sebanyak 404 siswi terdiri dari kelas X dan XI. Teknik sampling yang digunakan adalah simple random sampling sehingga didapat sampel sebanyak 110 siswi.
Data sindroma pramenstruasi (PMS) didapatkan dari Moos Menstrual Distress Questionnare (MDQ) yang berisi daftar gejala sindroma pramenstruasi (PMS). Kuesioner tersebut diambil dari penelitian ${ }^{2}$ diketahui ejala tersebut terdiri dari perut kembung, payudara terasa nyerti, pusing, sakit kepala, daerah panggul terasa berat dan tertekan, kelelahan luar biasa, kelainan kulit, nyeri perut bagian bawah, emosional, cemas, dan mudah tersinggung ${ }^{2}$. Kuisioner yang diberikan responden memuat gejala-gejala sesuai dengan penelitian ${ }^{2}$. Remaja putri dikatakan mengalami PMS jika mengalami minimal lima atau setengah dari 10 gejala menjelang menstruasi yang terakhir. Daftar gejala tifak dimodifikasi karena karakteristik responden sama.

Variabel yang diteliti adalah variabel independent berupa tingkat kecukupan karbohidrat dan persen lemak tubuh kemudian variabel dependent berupa sindroma pramenstruasi (PMS). Pengambilan data dilakukan dengan menggunakan pengukuran persen lemak tubuh menggunakan alat timbangan BIA merk omron dengan kedua tangan lurus kedepa membentuk 90으 terhadap badan dengan batas ketelitian neraca ohause dan kuesioner sindroma pramenstruasi (PMS) yang berisi 10 gejala yang serig dirasakan oleh wanita saat menjelang mentruasi dan Estimated Food Recall yang disertakan dengan panduan cara pengisian formulir tersebut.

Dan persen lemak tubuh yang didapatkan kemudian dianalisis menggunakan klasifikasi persentase lemak tubuh pada perempuan menurut Williams dan Don pada tahun 2002 yaitu underfat ( $\leq 15 \%)$, healthy (16-29\%), overfat $(30-34 \%)$, dan obese $(\geq 35 \%)^{27}$. Data pola konsumsi yang dikonsumsi yang diperoleh merupakan susunan jenis dan jumlah pangan yang dikonsumsi oleh responen remaja putri pada waktu tertentu. Pengumpulan data dilakukan menggunaka alat bantu Estimated Food Recall yang diisi oleh responden selama $2 \times 24$ jam pengukuran dengan hari yang tidak beurutan yaitu weekday dan weekend. Pada saat pengumpulan data, peneliti memilih untuk mewawancarai responden pada 2 hari, yaitu hari rabu dan sabtu. Penyeragaman hari pengumpulan data adalah umtuk meminimalisasi bias yang terjadi terkait kebiasaan makan responden. Responden sebelumnya telah diberikan pengarahan mengenai cara mengsi formulir Estimated Food Recall serta dilampirkan pula panduan cara pengisian formulir Estimated Food Recall tersebut. Kejadian sindroma pramenstruasi dikategorikan mengalami PMS jika merasakan minimal 5 gejala PMS dan Tidak mengalami PMS jika tidak merasakan gejala PMS. Uji Hubungan dilakukan dengan uji korelasi Spearman dengan $\alpha=0,05$. Uji korlasi Spearman dapat digunakan untuk data kategorikal dengan minimal skala data ordinal ${ }^{28}$. Uji korelasi Spearman dilakukan pada penelitian ini mengggunakan skala data ordinal pada kedua variabel. Penelitian ini telah mendapatkan persetujuan dari komisi etik Fakultas Keperawatan Universitas Airlangga dengan nomor 1774-KEPK.

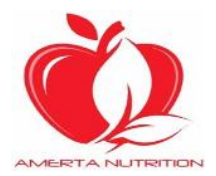

(C)2020. Rahmadianta dan Adiningsih. Open access under CC BY - SA license.

Received: 02-11-2019, Accepted: 10-01-2020, Published online: 15-03-2020.

doi: 10.20473/amnt. v4i1.2020. 23-29 Joinly Published by IAGIKMI \& Universitas Airlangga 


\section{HASIL DAN PEMBAHASAN}

Berdasarkan dari penelitian yang telah dilakukan dapat dilihat bahwa dari 110 responden dapat dilihat pada Tabel 1, didapatkan bahwa sebanyak 92 orang $(83,7 \%)$ responden tergolong dalam kategori asupan karbohidrat yang kurang dan bahan makanan sumber karbohidrat yang paling sering dikonsumsi setiap hari oleh responden adalah nasi yaitu sebesar $100,0 \%$, sedangkan sumber karbohidrat yang tidak pernah dikonsumsi oleh responden adalah oat yaitu sebesar $91,8 \%$. Dalam penelitian ini, mayoritas responden tergolong dalam kategori memiliki asupan karbohidrat yang kurang. Hal ini karena remaja putri cenderung mengurangi asupan karbohidrat yang bertujuan untuk mendapatkan bentuk tubuh yang langsing. (SITASI). Selain itu, makanan pokok terbanyak yang ditemui dalam hasil penelitian ini adalah nasi. Hal ini wajar terjadi karena di lingkungan penelitian nasi merupakan makanan pokok yang sering dijumpai untuk makanan sehari-hari.

Tabel 1. Karakteristik Subyek Penelitian di SMA Negeri 4 Bojonegoro Tahun 2019.

\begin{tabular}{llll}
\hline $\begin{array}{l}\text { Subjek } \\
\text { penelitian }\end{array}$ & Karakteristik & Jumlah & $\begin{array}{l}\text { Persentase } \\
\text { (\%) }\end{array}$ \\
\hline Jenis kelamin & Perempuan & 110 & 27,2 \\
\hline Usia & $\begin{array}{l}\text { Remaja usia : } \\
\text { 14 tahun }\end{array}$ & 1 & 0,9 \\
& 15 tahun & 39 & 35,5 \\
& 16 tahun & 60 & 54,5 \\
& 17 tahun & 10 & 9,1 \\
Berat Badan & $\leq 50 \mathrm{~kg}$ & 56 & 50,9 \\
(kg) & $\geq 50 \mathrm{~kg}$ & 54 & 49,1 \\
Tinggi $\quad$ Badan & $\leq 150 \mathrm{~cm}$ & 30 & 27,3 \\
(cm) & $\geq 150 \mathrm{~cm}$ & 80 & 72,7 \\
& $\leq$ Rata-rata & 63 & 57,3 \\
Besar $\quad$ Uang & (Rp. 383.364) & 47 & 42,7 \\
Saku & $\geq$ Rata-rata & & \\
& (Rp. 383.364) & & \\
\hline
\end{tabular}

Tingkat kecukupan karbohidrat responden tidak memenuhi angka kecukupan karbohidrat yang ada di AKG. Tingkat kecukupan karbohidrat pada remaja putri usia 1618 tahun adalah sebesar 368 gram $/$ hari $^{29}$. . Berdasarkan hasil penelitian menggunakan metode recall $2 \times 24$ jam didapatkan bahwa sebagian besar asupan karbohidrat responden berada di bawah kecukupan AKG, yakni sebesar 152,1 gram/hari.Karaktekteristik remaja yang cenderung memperhatikan body image menyebabkan mereka membatasi asupan makanan yang mengandung karbohidrat dan berdampak pada kurangnya asupan gizi yang dikonsumsi ${ }^{16}$ Tingkat kecukupan gizi baik kurang maupun lebih dapat berpengaruh terhadap sindroma pramenstruasi. Apabila seseorang mengonsumsi makanan yang mengandung karbohidrat kurang dari kebutuhan, maka dapat mengalami sindroma pramenstruasi ${ }^{24}$. Kurangnya tingkat kecukupan karbohidrat pada remaja dipengaruhi oleh beberapa hal seperti kesibukan remaja dipengaruhi oleh beberapa hal seperti kesibukan remaja mengikuti berbagai kegiatan sehingga melupakan waktu makan. Selain itu,karakteristik remaja yang memperhatikan body image utamaya pada remaja perempuan yang ingin memiliki tubuh langsing menyebabkan mereka melakukan pengaturan pola makan yang terlalu ketat demi menjaga penampilannya yang berdampak pada status gizinya ${ }^{16}$. Pola makan remaja cenderung mengurangi jumlah bahan sumber karbohidrat karena ingin memiliki tubuh ideal sehingga berdampak pada tingkat kecukupan karbohidrat karena ingin memiliki tubuh yang ideal sehingga berdampak pada tingkat kecukupan karbohidrat merupakan zat gizi makro yang paling banyak menyumbang energi. Remaja putri didentifikasi sebagai kelompok khusus yang rentan terhadap efek kekurangan gizi.

Persen lemak tubuh merupakan salah satu faktor dalam penentuan status gizi apabila besar lemak tubuh perempuan berkisar $25-30 \%$ termasuk kategori normal ${ }^{30}$. Berdasarkan penelitian di SMA Negeri 4 Bojonegoro kelas X dan XI pada remaja putri didapatkan di Tabel 3, dapat dilihat bahwa nilai pengukuran persen lemak tubuh menggunakan Bioelectrical Impedance Analysis (BIA) terhadap responden. Dari 110 orang responden sebagian besar termasuk dalam kategori komposisi persen lemak tubuh kategori overfat sebanyak $17,3 \%$, obese sebanyak $8,2 \%$, dan underfat sebesar $1,8 \%$ dengan jumlah rata-rata persen lemak tubuh respondenn yaitu $25,9 \%$. Berdasarkan hasil penelitian bahwa sebagian besar responden yang tergolong kategori overfat $(17,3 \%)$ s Dapat diartikan bahwa sebagian besar responden memiliki persen lemak tubuh yang tidak lebih dari normalnya.

Tabel 3. Distribusi Persen Lemak Tubuh Siswi Kelas X dan XI di SMA Negeri 4 Bojonegoro Tahun 2019.

\begin{tabular}{ccl}
\hline Persen Lemak Tubuh & Jumlah (n) & Persentase (\%) \\
\hline Underfat : $\leq 15 \%$ & 2 & 1,8 \\
Healthy : $16 \%-29 \%$ & 80 & 72,7 \\
Oberfat : $30 \%-34 \%$ & 19 & 17,3 \\
Obese : $\geq 35 \%$ & 9 & 8,2 \\
\hline \multicolumn{3}{c}{ Rata-rata $=25,9 \% \pm 4,9 \% ;$ Minimum $=14,7 \%$; } \\
\multicolumn{3}{c}{ Maksimum = 37,7\% } \\
\hline
\end{tabular}

Konsumsi makanan tinggi karbohidrat seperti makanan dengan rasa yang sangat manis selama fase luteal dapat meningkatkan keluhan emosi, depresi, dan kelelahan pada penderita $\mathrm{PMS}^{31}$. Berdasarkan penelitian di dapatkan lebih dari separuh responden remaja putri di SMA Negeri 4 Bojonegoro tergolong tingkat kecukupan kurang karbohidrat $(<80 \%)$ yaitu sebanyak 92 orang $(83,7 \%)$. Sedangkan berdasarkan klasifikasi yang ada, nilai ini termasuk kategori kurang. Persen lemak tubuh yang

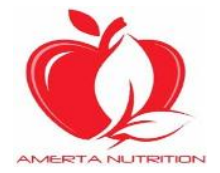

(C)2020. Rahmadianta dan Adiningsih. Open access under CC BY - SA license.

Received: 02-11-2019, Accepted: 10-01-2020, Published online: 15-03-2020.

doi: 10.20473/amnt. v4i1.2020. 23-29 Joinly Published by IAGIKMI \& Universitas Airlangga 
paling umum diukur yaitu jaringan lemak tubuh total dan jaringan bebas lemak ${ }^{32}$. Namun, pada penelitian ini mengukur jaringan lemak tubuh total responden didapatkan sebesar $72,7 \%$ responden memiliki persen lemak tubuh yang healthy. Cut off point persen lemak tubuh yang digunakan untuk mengklasifikasikan kelebihan lemak tubuh khusnya adalah $\geq 30 \%{ }^{27}$. Rata-rata persen lemak tubuh responden remaja putri di SMA Negeri 4 Bojonegoro yaitu $25,9 \%$, berdasarkan klasifikasi yang ada nilai ini termasuk dalam kategori persen lemak tubuh sehat (healthy). Gejala sindroma pramenstruasi terjadi pada wanita berupa perut kembung, payudara terasa nyeri, pusing, sakit kepala, daerah panggul terasa berat dan tertekan, kelelahan yang luar biasa, kelainan kulit, nyeri perut bagian bawah, emosional, cemas, dan mudah tersinggung ${ }^{2}$ Hasil data kejadian Sindroma Pramenstruasi (PMS) menunjukkan sebanyak 63 orang remaja putri
$(57,2 \%)$ mengalami sindroma pramenstuasi (PMS) pada periode mentruasi terakhir kali. Walaupun kejadian sindroma Pramenstruasi (PMS) tidak mengancam nyawa, namun dapat mempengaruhi produktivitas dan kesehatan mental seorang wanita ${ }^{33}$. Berdasarkan data penelitian yang di lakukan di SMA Negeri 4 Bojonegoro menunjukkan bahwa pada tahun 2019 sebanyak 94 oramg mengalami kekurangan tingkat kecupan karbohdrat sebesar 85,0\% dan mengalami tingkat kecukupan energi sebanyak 16 orang sebesar $14,5 \%$. Sedangkan remaja putri di SMA Negeri 4 Bojonegoro yang mengalami sindroma pramenstruasi (PMS) sebanyak 86 orang (78,2\%). Penelitian menurut peneltian Nurmiati tahun 2011 menyatakan bahwa asupan tinggi karbohirdrat dan asupan tinggi lemak akan meningkatkan suatu resiko terjadinya sindroma pramenstruasi ${ }^{25}$.

Tabel 2. Hasil Recall Siswi Kelas X dan XI di SMA Negeri 4 Bojonegoro Tahun 2019.

\begin{tabular}{|c|c|c|c|c|c|c|c|}
\hline Asupan & Klasifikasi & Jumlah (n) & $\begin{array}{c}\text { Persentase } \\
\text { (\%) }\end{array}$ & Mean \pm SD & Median & Maximum & Minimum \\
\hline \multirow[t]{3}{*}{ Energi (kkal) } & Kurang $(<80 \%)$ & 80 & 72,7 & $68,8 \pm 60,5$ & 56,5 & 601,3 & 5,0 \\
\hline & Cukup (80-110\%) & 16 & 14,5 & & & & \\
\hline & Lebih (>110\%) & 14 & 12,7 & & & & \\
\hline \multirow[t]{3}{*}{ Karbohidrat (g) } & Kurang (<80\%) & 92 & 83,7 & $52,1 \pm 26,0$ & 46,0 & 133,6 & 10,6 \\
\hline & Cukup (80-110\%) & 15 & 13,6 & & & & \\
\hline & Lebih (>110\%) & 3 & 2,7 & & & & \\
\hline \multirow[t]{3}{*}{ Protein (g) } & Kurang (<80\%) & 56 & 50,9 & $92,2 \pm 50,5$ & 79,7 & 293,2 & 13,6 \\
\hline & Cukup (80-110\%) & 22 & 20,0 & & & & \\
\hline & Lebih $(>110 \%)$ & 32 & 29,1 & & & & \\
\hline \multirow[t]{3}{*}{ Lemak (g) } & Kurang (<80\%) & 60 & 54,5 & $90,5 \pm 58,4$ & 73,2 & 431,0 & 7,0 \\
\hline & Cukup (80-110\%) & 21 & 19,1 & & & & \\
\hline & Lebih (>110\%) & 29 & 26,4 & & & & \\
\hline
\end{tabular}

Tabel 4. Hasil Crosstab Tingkat Keckupan Karbohidrat, Persen Lemak Tubuh, dan PMS pada remaja putri di SMA Negeri 4 Bojonegoro Tahun 2019.

\begin{tabular}{|c|c|c|c|c|c|c|c|c|}
\hline \multirow{3}{*}{ Variabel } & \multicolumn{4}{|c|}{ Kejadian Sindroma Pramenstruasi } & \multirow{3}{*}{ Jumlah (N) } & \multirow{3}{*}{$\begin{array}{c}\text { Persentase } \\
\text { (\%) }\end{array}$} & \multirow{3}{*}{ P dan r Value } & \multirow{3}{*}{ Signifikansi } \\
\hline & \multicolumn{2}{|c|}{ Tidak PMS } & \multicolumn{2}{|c|}{ PMS } & & & & \\
\hline & $\mathbf{n}$ & $\%$ & $\mathbf{n}$ & $\%$ & & & & \\
\hline \multicolumn{7}{|c|}{ Persen Lemak Tubuh } & \multirow{5}{*}{$\begin{array}{l}P=0,642 \\
r=-0,045\end{array}$} & \multirow{5}{*}{$\begin{array}{c}\text { Tidak } \\
\text { signifikan }\end{array}$} \\
\hline Underfat & 0 & 0,0 & 2 & 100,0 & 2 & 1,8 & & \\
\hline Healthy & 10 & 23,8 & 61 & 76,3 & 80 & 72,7 & & \\
\hline Overfat & 4 & 21,1 & 15 & 78,9 & 19 & 17,3 & & \\
\hline Obese & 1 & 11,1 & 8 & 88,9 & 9 & 8,2 & & \\
\hline \multicolumn{7}{|c|}{ Tingkat Kecupan Karbohidrat } & \multirow{5}{*}{$\begin{array}{c}P=0,010 \\
r=-0,246\end{array}$} & \multirow[t]{5}{*}{ Signifikan } \\
\hline Kurang & 22 & 23,9 & 70 & 76,1 & 92 & $83,6 \%$ & & \\
\hline Cukup & & & & & 15 & & & \\
\hline \multirow[t]{2}{*}{ Lebih } & 2 & 13,3 & 13 & 86,7 & 3 & $13,6 \%$ & & \\
\hline & 0 & 0,0 & 3 & 100,0 & & $2,7 \%$ & & \\
\hline
\end{tabular}

Menggunakan uji korelasi spearman pada Persen Lemak Tubuh dan KH dengan PMS Berdasarkan dari hasil penelitian yang dilakukan dapat dilihat bahwa dari 110 responden. Dapat dilihat pada tabel 4 bahwa remaja putri yang tidak cukup mengonsumsi karbohidrat, sebagian besar mengalami sindroma pramenstruasi (PMS) 76,1\%Remaja putri yang mengonsumsi cukup karbohidrat sebagian besar tidak mengalami sindroma pramenstruasi (PMS) $13,3 \%$ Hasil uji statistik dengan menggunakan uji spearman, menunjukkan bahwa hubungan tingkat kecukupan karbohidrat dengan kejadian sindroma pramenstruasi (PMS) memiliki nilai $\mathrm{p}$

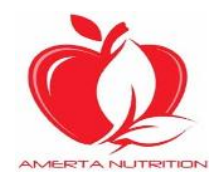

C 2020. Rahmadianta dan Adiningsih. Open access under CC BY - SA license.

Received: 02-11-2019, Accepted: 10-01-2020, Published online: 15-03-2020.

doi: 10.20473/amnt. v4i1.2020. 23-29 Joinly Published by IAGIKMI \& Universitas Airlangga 
sebesar 0,010 menunjukkan adanya hubungan yang signifikan antara tingkat kecukupan karbohidrat dengan kejadian sindroma pramenstruasi (PMS).

Hal tersebut sejalan dengan penelitian yang menyatakan bahwa asupan karbohidrat selama fase luteal sampai dengan darah menstruasi keluar dapat mengurangi gejala sindroma pramenstruasi. Hasil penelitian lain menurut Marmi tahun 2013 bahwa asupan karbohidrat berpengaruh dalam memprediksi dengan suatu kejadian sindroma pramenstruasi pada remaja putri karena semakin tinggi asupan karbohidrat maka resiko mengalami sindroma pramenstruasi 0,9 kali lebih rendah, disebabkan karena asupan karbohidrat secara konsisten mempertahankan kadar serotonin (suatu zat kimia otak) sehingga memakan makanan yang mengandung karbohidrat akan dapat mngendalikan perubahan mood. Selain itu karbohidrat adalah sumber utama energi tubuh. Jika asupan karbohidrat kurang secara drastis akan menyebabkan berbagai efek samping seperti kelelahan yang luar biasa, sakit kepala, sakit perut, menstruasi lambat, dan diare ${ }^{34}$.

Hasil uji statistik dengan menggunakan uji spearman dapat dilihat di tabel 4, menunjukkan bahwa hubungan antara persen lemak tubuh dengan kejadian sindroma pramenstruasi (PMS) dengan hasil korelasi spearman menunjukkan memiliki nilai $(p>0,05)$ yaitu 0,642 . Memiliki koefisien korelasi sebesar $-0,045$, hal ini menunjukkan tidak adanya hubungan yang signifikan antara komposisi persen lemak tubuh dengan sindroma pramenstruasi (PMS). Hal tersebut mendukung hasil penelitian Purwanti pada tahun 2006 yang menggunakan metode dan usia subjek penelitian yang sama serta subjek penelitian yang hampir sama, bahwa tidak ada hubungan nyata antara persen lemak tubuh dengan sindroma pramenstruasi (PMS) ${ }^{35}$. Penelitian Niken pada tahun 2013 juga membuktikan bahwa persen lemak tubuh dengan ketaraturan menstruasi, lama menstruasi, dismenore atau $\mathrm{PMS}^{36}$. Tetapi ada pengecualian pada subjek yang melakukan aktivitas senam dan menari, sehingga diduga partisipasi olahraga memiliki dampak pada pola menstruasi. Selain itu juga didapatkan hasil hubungan signifikan antara tingkat stress dengan PMS, sedangkan pada penelitian yang dilakukan tidak melihat hubungan antara aktivitas fisik dan tingkat stress terhadap keluhan PMS. Hasil penelitian Destianapada tahun2017 pada atlet wanita juga menunjukkan bahwa tidak ada hubungan yang signifikan antara persen lemak tubuh dan panjang siklus maupun keluhan menstruasi ${ }^{37}$. Penelitian ini menegaskan bahwa menstruasi tidak dapat didefinisikan sebagai fenomena patologis yang terjadi sendiri. Sebaliknya, kejadian menstruasi pada masing-masing individu mungkin lebih sesuai dievaluasi menurut multivariable pola menstruasi yang kontinum, bukan hanya cross sectional study. Penelitian ini menunjukkan bahwa kejadian sindroma pramenstruasi dapat mempengaruhi tingkat kecukupan karbohidrat subyek namun tidak mempengaruhi persen lemak tubuh subyek di SMA Negeri 4 Bojonegoro. Berdasarkan penelitian ini, hendaknya pihak sekolah menambahkan pengetahuan dasar terkait gizi dan kesehatan dalam kurikulum sehingga baik siswa, guru dan wali murid memahami pentingnya gizi dan kesehatan. Penelitian ini telah dilaksanakan sesuai dengan prosedur ilmiah, namun masih terdapat keterbatasan seperti farktor lain yang dapat mempengaruhi sindroma pramenstruasi dan persen lemak tubuh, selain itu keterbatasan tempat untuk melakukan recall kepada subyek dengan didengar oleh teman sebelahnya atau dibelakangnya dan menjadikan hasil penelitian menjadi bias.

\section{KESIMPULAN}

Hasil penelitian diperoleh bahwa terdapat hubungan antara tingkat kcukupan karbohidrat dengan sindroma pramenstruasi, serta tidak terdapat hubungan antara persen lemak tubuh dengan sindroma pramenstruasi. Untuk mengurangi kejadian sindroma pramenstruasi pada remaja putri, dapat dilakukan edukasi mengenai makanan seimbang yang dikaitkan dengan sindroma pramenstruasi.kebutuhan dapat meningkatkan resiko terhadap kejadian sindroma pramenstruasi (PMS) pada remaja putri di SMA Negeri 4 Bojonegoro. Untuk meningkatkan asupan karbohidrat, disarankan remaja putri mengonsumsi karbohidrat sesuai dengan tingkat kecukupan menurut AKG

\section{ACKNOWLEDGEMENT}

Terima kasih disampaikan kepada pihak SMA Negeri 4 Bojonegoro yang telah memberikan ijin melaksanakan penelitian di SMA Negeri 4 Bojonegoro, serta kepada siswi kelas $\mathrm{X}$ dan $\mathrm{XI}$ yang telah bersedia menjadi responden penelitian.

\section{REFERENSI}

1. Estiani, K. \& Nindya, T. S. Hubungan Status Gizi Dan Asupan Magnesium Dengan Kejadian Premenstrual Syndrome (Pms) Pada Remaja Putri. Media Gizi Indones. 13, 20 (2018).

2. Devi, M. Hubungan Kebiasaan Makan dengan Kejadian Sindroma Pramenstruasi. Teknol. dan Kejuru. 32, 4 (2009).

3. Pudiastuti, R. . 3 Fase Penting Pada Wanita. 2012.

4. Retisu, R., Muhaimin, A. \& Rujito, L. Hubungan Indeks Massa Tubuh dengan Sindroma Pramenstruasi. 1-6 (2010).

5. Ramadani, M. Premenstrual Syndrome (PMS). Kesehat. Masy. 7, 1 (2012).

6. Wijaya. Atlas Teknik Kebidanan. (EGC, 2008).

7. Christiani, I. Hubungan Status Gizi, Asupan Zat Gizi Mikro (Kalsium, Magnesium) dengan Sindroma Pramenstruasi Pada Remaja Putri SMU Sejahtera

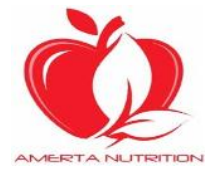

(C)2020. Rahmadianta dan Adiningsih. Open access under CC BY - SA license.

Received: 02-11-2019, Accepted: 10-01-2020, Published online: 15-03-2020.

doi: 10.20473/amnt. v4i1.2020. 23-29 Joinly Published by IAGIKMI \& Universitas Airlangga 
di Surabaya. (2007).

8. Solomon, C. . et al. Long or Highly Irregular Menstrual Cycles As A Marker For Risk of Type 2 Dibetes Mellitu. Am. Med. Assos. 2421-2426 (2002).

9. Riskesdas. Metodologi Penelitian Kesehatan. (2010).

10. Talitas, B. \& Sianipar, M. Intellectual Capital and Its Impact on Financial Profitalitas and Investor Capital Gain on Share. 15, (2009).

11. Chung, N. . Impact of Seasonal Climate Variability on Rice Production in the Central Highlands of Vietnam. Agiculture Agicultural Sci. Prosedia 5, 83-88 (2015).

12. Arnati, W. Penyelenggaraan Makanan dan Tingkat Kepuasan Konsumen di Kantin Zea Mays Institute Peranian Bogor. 2, 10-16 (2013).

13. Amelia, R. W. Hubungan Antara Indeks Massa Tubuh dan Faktor-Faktor Lain dengan Status Gizi Unit Rawat Inap Terpadu Gedung A RSUPN Dr Cipto Mangunkusumo. vol. 2 (2009).

14. Satoto. Kegemukan: Obesitas dan Penyakit Degeneratif, Epidemiologi dan Strategi Penanggulangan. (Widyakarya Nasional Pangan dan Gizi VI, LIPI, 1998).

15. Barasi, M. Nutrition at Glance. (Erlangga, 2009).

16. Adriani, M. \& Wirjatmadji, B. Peranan Gizi dalam Siklus Kehidupan. (2016).

17. Sitoayu, L., Pertiwi, D. A. \& Mulyani, E. Y. Kecukupan Zat Gizi Makro, Status Gizi, Stress, dan Siklus Menstruasi pada Remaja. Gizi Klin. Indones. 13, 2502-4140 (2017).

18. Manuaba. IImu Kebidanan Penyakit Kandungan dan KB. (EGC, 2010).

19. Lutfi, S. Makan Teratur Mahasiswa Tingkat Akhir. http://lutiblurry.com (2011).

20. Isnaeni, D. . Hubungan antara Stress dengan Pola Menstruasi pada Mahasiswa DIV Kebidanan Jalur Reguler. (2010).

21. Acharya, A., Reddaiah, V. . \& Baridalyne, N. Nutritional Status and Menarche in Adokescent Girl in an Resettlement Colony of South Delhi. 4, 302-303 (2006).
22. Johnson, L. Buku Ajar Keperawatan Keluarga. (Nuha Medika, 2010).

23. Chen, S. \& Parmigiani, G. Mrta-analysis of BRCA 2 Penetrance Journal of Clinical Oncology. 25, 1329-1333 (2007).

24. Mommies. Senam Hamil. (Rineka Cipta, 2005).

25. Nurmiaty. Perilaku Makan dengan Kejadian Sindroma Pramenstruasi pada Remaja. (2011).

26. Agustina, T. Kontaminasi Logam Berat Pada Makanan dan Dampaknya Pda Kesehatan. Tejnubuga 2, 53-65 (2010).

27. Bloom, W. \& Don, W. Prostate Cancer. (2002).

28. Riadi, E. Statistika Penelitian. AndiPublisher (2016).

29. AKG. Angka Kecukupan Gizi Energi, Protein, Lemak, Mineral dan Vitamin yang di Anjurkan Bagi Bangsa Indonesia. Lampirab Peratur. Menteri Kesehat. Republik Indones. 75, (2013).

30. Hill, N., L Oke, J., O' Callaghan, C. ., Lasserson, D. \& Richard Hobbs. Global Prevelance of Chronic Kidney Disease - Asystematic Review and MetaAnalysis. 11, (2016).

31. Waldman, D. A. The Contribution of Total Quality Mnagemnent to a Theory of Work Performance, Academy of Management Riview. 19, 210 (1994).

32. Suparisa. Penilaian Status Gizi. (EGC, 2011).

33. Bungsari, S. . Gambaran Sindroma Prahaid pada Remaja Putri. 3, (2015).

34. Marmi. Gizi Dalam Kesehatan Reproduksi. (Pustaka Belajar, 2013).

35. Purwanti, E. Hubungan Persen Lemak Tubuh, Aktivitas Fisik dan Frekuensi Olahraga dengan Siklus Menstruasi pada Siswi SMAN 9 Semarang. (Diponegoro, Semarang, 2006).

36. Niken. Hubungan Indeks Massa Tubuh dan Persen Lemak Tubuh dengan Sindroma Pramenstruasi Pada Remaja Putri di SMA Bina Insani Bogor. Gizi Masy. 3, (2013).

37. Destiana. Hubungan Antara Pola Makan dan Persentase Lemak Tubuh Terhadap Kebugaran Jasmani Atlet Takwondo Terhadap Sindroma Pramenstruasi. Kesehat. Masy. 8, (2017). 